\author{
By Segundo V. Linares Quintana $\dagger$
}

While the following article was in the process of publication, $a$ Constitutional Convention of 169 members adopted a new Constitution for the Argentine Republic; however, the significant changes effected by this new Constitution indicate that the problems raised herein are still germane.

This new Constitution is made up of 103 Articles and one Temporary Article, as compared with the 110 Articles of the old Constitution. It shows a decided tendency to recognize the advancement of the social and economic rights of all the people, as indicated by the Articles concerning the rights of workmen and the family, of education and culture for all, and the determination of the social functions of property. Among the most significant changes are the provisions permitting the re-election of the President and Vice-President for more than one term of six years, and for the election of Senators and Deputies for terms of six years. Another major innovation of particular interest is the provision extending Argentine citizenship automatically to all foreigners who have resided in Argentina five years unless the foreigner signifies in writing his intention not to become a citizen.

The whole spirit of this new Constitution is presumably expressed in the amendment to the Preamble, which adds, after setting forth the purposes of "confirming justice, consolidating domestic peace, providing for the common defense, promoting the general welfare . . .," the language: ". . . ratifying the inexorable decision to constitute a nation, socially just, economically free and politically sovereign. . . ."

Where pertinent, comment has been inserted to indicate the changes which have been effected by the new Constitution.-ED.

$\doteqdot$ LL. B., 1933, S. J. D., 1936, Faculty of Law and Social Sciences of Buenos Aires. Winner of Mario Carranzo, Nazar Anchorena and other prizes. Author, GobIerno Y ADMINISTRACTON DE LA REPÚBLICA ARGENTINA (1946) ; DERECHO CONSTITUCTONAI SOVIETÍCO (1946); Los PARTIDOS POLITICOS EN Estados UNmOS (1945) ; CoNSTITUCIONALISMO Y IIBERTAD (1945), and many other publications. Former Legislative Advisor of the Library of Congress, Director of the Department of Labor in the Province of Buenos Aires, Director-General of Penal Establishments in the Province of Buenos Aires.

Translated by Carlos Berguido, Jr., A. B., 1919, LL. B., 1922, University of Pennsylvania. Member of the Pennsylvania Bar; Panamanian Consul in Philadelphia, Pennsylvania; author, various articles and book reviews in legal periodicals. 


\section{THEORY OF THE Constitution}

\section{Influence of the Constitution of the United States on the Constitution of the Argentine Republic}

When Doctor Nicolás A. Calvo published the Spanish version of Story's Commentary on the Constitution of the United States in 1860 , he stated that his translation was to serve so that his compatriots "might become aware of the value of the Argentine federal Constitution, which has been copied from the United States Constitution; and which has no defects except precisely in those points in which it ceases to be a copy." 1

The validity of such a categorical assertion should be examined. In support there could immediately be cited expressions of the representatives to the Constitutional Congress of $1853,{ }^{2}$ and the minutes of the declaration which the Congress itself approved. ${ }^{3}$ But the question has resulted in a strenuous and impassioned controversy between Domingo Faustino Sarmiento and Juan Bautista Alberdi, two of the greatest thinkers Argentina has ever produced. The former maintains that the preamble to the American Constitution was adopted literally, with the result that "American constitutional law, the doctrine of its statesmen, the declarations of its courts, the customary practice in identical or analogous questions have the force of authority in the Argentine Republic. . . ."4 On the other hand, Alberdi, who has acquired the title of Father of the Constitution because of the profound influence his ideas had on the Constitutional Congress of 1853, states that "everything is different in the two constitutions . . . even though the federal form which is common to both, makes them appear similar to the eyes of the inattentive and superficial observer." He then goes on to point out that to compare the fundamental Argentine law with that of the United States is but to "falsify and bastardize" the former. ${ }^{5}$

The truth lies somewhere in between these two extremes. It is not conceivable that the Argentine Constitution is a mere servile copy of the United States Constitution, but neither is it correct to say

1. 1 Calvo, JoHn Story, Comentarto sobre la Constituctón federal de ios Estados UNIDOS 2 (1888). (Emphasis added.)

2. See remarks of Representatives Gorostiaga and Gutierres, REPúBLICA ARGENTINA, CONVENCIÓN NACIONAL DE 1898 Y ANTECEDENTES; CONGRESO CONSTITUYENTE DE 1853 Y CONVENCIONES REFORMADORAS DE 1860 Y 1866 at 270,283 (1898).

3. Id. at 369.

4. Sarmiento, Comentarios de la Constitución de la Confederación ArgenTINA 54 (1929).

5. Alberdi, Bases y comentaruos a la Constitución Argentina 335, 346 (1929). 
that the admirable code of the United States has not had a profound influence on the instrument of government of Argentina. Argentine scholars, including J. N. Matienzo, ${ }^{6}$ Joaquin V. González, ${ }^{7}$ Juan A. González Calderón, ${ }^{8}$ Alberto Padilla, ${ }^{9}$ and American authorities as well, viz., Dowling ${ }^{10}$ and MacDonald, ${ }^{11}$ subscribe to this middle-ofthe-road view.

In reality the Argentine Constitution is not a copy or imitation of that of the United States, nor is it the miraculous result of inspiration. It is the product of years of struggle and sacrifice, created laboriously through the efforts of generations of Argentines. Each one of its articles, each one of its clauses, each one of its words, has deep roots in the history of the nation. But the members of the Santa Fe Congress of 1853, in addition to national antecedents and characteristics, took into consideration the conclusions of political science and comparative constitutional law, and above all, the principles of the Constitution of the United States, which served and still serves as a model for federal republics, and the adoption of which marked the beginning of a new era in political science. It would not be an exaggeration to say that the instrument of government drafted at Philadelphia, like the polar star which directs navigation, has been the compulsory force point of the democratic peoples of the world. ${ }^{12}$ It seems perfectly clear, therefore, that the Fathers of the Argentine Constitution took as a mould or model the American Constitution, taking into consideration at the same time the antecedents and peculiarities of their country in order to produce a praiseworthy instrument of government, the value of which made the Italian jurist, Victor $M$. Orlando, say that it would seem that the Argentine drafters acted as if inspired by God. ${ }^{13}$

6. See Matienzo, El gobierno Representativo federal 86 (1910).

7. See 1 González, Estudios constituctonales 11 (1930).

8. See 1 Calderón, Derecho constituctonal 422 (1931).

9. Padilia, la Constitución de Estados Unidos como precedente argentino 8 (1921).

10. Dowling, Paralelos constitutionales entre la Argentina y los Estados Unidos, 22 ReVISTA ARgENTINA JuRIDICA, LA LEY [hereinafter REV. LA LEY] 1 (Argentina 1941).

11. MacDonald, Government of the Argentine Republic 128 (1942).

12. Compare the remarks in 1 NITrI, LA DEMocraciA 43 (Almela \& Vives ed. 1932); Viamonte, La Revolución Norteamericana y la Revolución Francesca, La Nación, Sept. 5, 1948, §2, p. 1. It should be noted that the report of the Commission studying the Argentine Constitution of 1860 appraised the Constitution of the United States as "the only one which has authority throughout the world." DIARIO DE SESIONES DE LA CoNvenctón del Estado de Buenos AIRes encargada det examen de la ConstTtuctón Federat 95 (1860).

13. Orlando, Carácter de la Constitución Argentina, 18 Revista de Legrseación y JURISPRUDENCIA [hereinafter REV. JUR. ARGENTINA] 121 (1921). 


\section{Comparison of the Text of the United States and Argentine Constitutions}

A comparison of the two constitutions shows that forty-four sections of the two are practically identical, twenty-two are similar, fortyone are different, and sixty sections of the Argentine Constitution are not found in the American. ${ }^{14}$

A detailed and impartial comparison evidences great and fundamental similarities, manifestly due to the use of the American Constitution as a model. With complete accuracy Professor MacDonald states, ". . . when an American visitor examines for the first time the Argentine Constitution he receives a certain surprise, the surprise of a person who has traveled many thousands of miles from his land, only to discover the smiling face of an old friend. The declaration of rights formulates the same guarantees of individual liberty which have been known for so long by generations of Americans and which the English people enjoyed even much earlier. The powers of the President and of the Congress, the relation between the nation and the provinces, the organization and functioning of the courts, as these matters are established in the fundamental Argentine law all carry the indelible stamp of the authors of the American Constitution of 1787." 15

It has been averred that the law of the United States is based on four cardinal principles:

(A) Representative government-the determination of legislation by representatives elected by the people, and not by the people themselves;

(B) Dual government-the concept that each American citizen is a citizen both of his respective state and of the central government within their respective spheres;

(C) Guarantee of individual liberty-the limitations on the public powers;

(D) Independent judicial power-the inability of the other branches of the government to exercise dominance over the judiciary. ${ }^{10}$

14. For a detailed comparison of the sections appearing mutually and individually in the two constitutions, see VIAMONTE, MANUAL DE DERECHO CONSTITUCTONAL 355361 (1944). In this work is included the text of the Argentine Constitution, in which appear in italics the parts that are not in the United States Constitution. Id. at 362-380.

15. MacDonald, Impresiones de un estudio norteamericano de ciencia politica sobre el gobierno argentino, 26 REv. LA LEY 947 (1942).

16. Marsh, El canon amertcano 62 (1941). 
Chief Justice Marshall's statement that "the government of the United States is a government of laws and not of men" summarizes the whole political philosophy of the American Constitution. And the Argentine Constitution, even though it may differ in detail, has been built on identical foundations, and is inspired by the same political philosophy.

But this does not import a denial of the deep differences which exist in the details of the architecture of the two instruments. For example, the Argentine law inclines toward more federal power, as opposed to state power, than the United States, from which it follows that the states of the United States enjoy a greater self-government than the provinces of Argentina. Moreover, in Argentina the execttive appears to be vested with more powers than are granted the American President. On the other hand, the Argentine Constitution provides for the handling of the relations between the President and the Congress, an aspect which the American Constitution does not treat in detail. It will occasion no surprise, also, to point out that the United States Congress enjoys greater powers than the corresponding Argentine body.

With respect to individual liberty, both constitutions demonstrate a special concern, it being worthy of note that in the United States, the most powerful weapon for this preservation, the writ of habeas corpus, is suspended in national emergencies. In the Argentine Republic the equivalent situation is the declaration of the state of siege, the effect of which is to suspend individual guarantees.

\section{The Constitution in Practice}

\section{Individual Rights}

Both constitutions contain, implicit in every clause, the fundamental thesis that individual liberty is the raison-d'etre of the state. The preamble to the Argentine Constitution proclaims :

We the representatives of the people of the Argentine nation, in General Constitutional Congress assembled, by the will and election of the Provinces which compose it; in fulfillment of preexisting pacts; for the purpose of . . . insuring the blessings of liberty for ourselves, our posterity, and for all the men of the world who wish to live on Argentine soil, invoking the protection of God, the fount of all reason and justice, do ordain, decree and establish this Constitution for the Argentine Nation.

The Argentine Supreme Court has decided that civil liberty is the end towards which constitutional government is aimed, political 
liberty being the means by which this end is to be achieved. In a memorable opinion, the court stated:

- . . the conjoint activity that would contradict the norms of social or personal morality or that could try to suppress the individual liberties insured to the inhabitants of the Republic by the first chapter of our fundamental Charter, and without the exercise of which man would be disqualified to perform with dignity his mission on this earth, would not be consistent with the legal character indicated; or, finally, that which would conspire against political liberty, because having been granted as the only means to insure civil liberty, in the long run the disappearance of the former will bring forth the enslavement of the latter. ${ }^{17}$

The Argentine drafters profited from the experience of the Philadelphia representatives and included a bill of rights in the Constitution itself, thus avoiding the problems of amendment and approval which confronted the American Constitution. It is of interest to contrast the bill of rights in the two constitutions. The American bill is obligatory only on the federal government, ${ }^{18}$ and lacks the proper force to limit state powers. ${ }^{10}$ The guarantees of the bill of rights are limited to the territory of the country, unincorporated territories being excluded unless fundamental rights are involved, in which case it is for the Supreme Court to determine what rights possess such character. ${ }^{20}$ On the other hand, the Argentine declaration of rights has full force in the whole national territory, both for the central government and the provincial governments for all inhabitants without exception. The provinces, upon accepting their constitutions, are obliged to do so in "accordance with the principles, declarations, and guarantees of the National Constitution." 21

The Fourteenth Amendment to the United States Constitution provides that no state shall deny to any person "the equal protection of the laws." Article Sixteen of the Argentine Constitution provides that ". . . the Argentine Nation does not admit prerogatives of blood or birth; there are not then any personal privileges or titles of nobility. All its inhabitants are equal before the law ${ }^{21 a}$ and admissible

17. In re Spagnuolo, 191 Fallos de la Corte Suprema de Justicia de la Nación [hereinafter C. S. N.] 388 (Argentina 1941).

18. Barron v. Baltimore, 7 Pet. 243 (U. S. 1833).

19. Powell v. Alabama, 287 U. S. 45 (1932); Near v. Minnesota, 283 U. S. 697 (1931). It must be noted that the Fourteenth Amendment imposes a limitation on the power of the states similar to the limitations imposed on the federal government by the Fifth Amendment.

20. Dorr v. United States, 195 U. S. 138 (1904) ; Downes v. Bidwell, 182 U. S. 244 (1901).

21. Hileret y Rodriguez v. Provincia de Tucumán, 98 C. S. N. 20, 39 (1903).

21a. Article Sixteen of the new Constitution adds, "The Nation of Argentina admits no racial separation or segregation." 
in positions without any other condition than competency. ${ }^{21 b}$ Equality is the basis of taxation and public charges."

The Supreme Court has reaffirmed many times that this section is to be read literally and that no privilege or exception may be established which operates for the benefit of a few. ${ }^{22}$ With special reference to taxes, the Court has laid down as the test of equality, that of equal burden upon the taxpayers in analogous circumstances, but has qualified this with the allowance of ample latitude to classify reasonably for taxation, holding that arbitrary taxation is unconstitutional. ${ }^{23}$

The Argentine Constitution differs from the American freedom of religion provision in that the Catholic Church is given a preferential status, by virtue of the fact that the government maintains the Catholic Church, and the President must be a Catholic. However, freedom of religion is guaranteed under Article Nineteen which states that ". . . private actions of men which in no manner whatever offend against public order and morality, or injure a third party, are reserved solely to God and exempt from the authority of the magistrates" and that ". . . no inhabitant of the nation shall be compelled to do what the law does not command nor be deprived of what it does not prohibit." And Article Fourteen guarantees to all inhabitants the right to profess freely their religion in accordance with the laws which regulate its exercise.

Freedom of speech is assured to the inhabitants of Argentina by Article Fourteen which gives them the right to "publish their ideas through the press without previous censorship", Article Thirty-two forbids the federal Congress from enacting laws "which may restrict the freedom of the press or which may establish federal jurisdiction over it." The concept of "previous censorship" prohibited by the Constitution is precise and comprehensive. The Supreme Court has held that this prohibition extends to the revision and examination of the written word for the purpose of controlling ideas before their publication as well as to such restrictions as bonds, permits, etc. Also included in this prohibition are measures punishing or suppressing the publication once it has appeared. ${ }^{24}$

21b. Article Fifteen of the new Constitution prohibits the employment by the government of any member of a national or international organization which espouses principles different from the principles of individual liberty recognized by the Constitution. Military organizations not controlled by the state are prohibited. Public use of uniforms, flags, symbols that characterize those organizations is prohibited.

22. See, e. g., United States Telephone Co. v. Municipalidad de la Capital Federal, 127 C. S. N. 18.

23. 153 C. S. N. $117 ; 149$ C. S. N. 417. (1932).

24. Ministerio Fiscal de Santa Fe v. "La Provincia," 40 Rev. Jur. Argentrina 310 
However, there should be distinguished two periods in the jurisprudence of the Argentine Supreme Court. From 1863 to 1932 it maintained consistently that federal courts had no jurisdiction over crimes committed by the press. But beginning with the case of Ministerio Fiscal de Santa Fe v. "La Provincia", decided December $23,1932,{ }^{25}$ the Court has held that federal courts have jurisdiction over these crimes, if there was a violation of those national laws which tended to insure against violence, to protect the existence of the central power, and to guarantee the exercise of constitutional powers.

The Ninth Amendment of the United States Constitution was adopted almost literally by the Amending Convention of the Argentine Constitution which met in 1860 as Article Thirty-three.

The writ of habeas corpus was not expressly adopted by the Argentine Constitution, but Article Eighteen provides that "no one may be arrested except by virtue of a written order from a competent authority." According to Argentine jurisprudence the remedy of habeas corpus will lie only in the case of an undue attack on physical liberty, even though decisions hold that this remedy applies to all individual rights which constitute personal liberty. Of late there has been a growing opinion in support of the constitutional existence of the remedy of amparo, directed to safeguard from the excesses of public authority the individual rights guaranteed by the Constitutionwith the exception of physical liberty which is protected by habeas corpus. $^{25 a}$ The decisions of the Argentine Supreme Court are confused on this point, and while decisions on both sides could be cited, the prevalent view is opposed to the existence of this remedy. ${ }^{26}$

In the United States, whenever the public safety is endangered by rebellion or invasion, the writ of habeas corpus is suspended. The parallel circumstance which will suspend the remedy in Argentina is the state of siege which may be declared by Congress or by the Executive with the consent of the Senate in the case of internal disorder and in the case of foreign attack.

Although according to the theory of the Constitution this remedy is exceptional and extraordinary, practically it has been converted into a normal event by the Congress so frequently has it been used. Since the constitutional organization of the country, the state of siege has been declared thirty times, twenty-nine of which were based on in-

25. Ibid.

25a. The new Constitution states that no citizen may be arrested without a written order from the proper authority, and all citizens have the right to the writ of habeas corpus to investigate any arrest or threat to individual liberty.

26. Compañia Sudamericana de Servicios Publicos S. A. v. Comisión de Fomento de Gálvez, 174 C. S. N. 184 (1935) ; J. G. Bertotto v. Jefe de Correos y Telégrafos de Rosario, 168 C. S. N. 31 (1933); In re Bertotto, 160 C. S. N. 113 (1931). 
ternal disorder. Fifteen of these times, it has been declared by execttive decree and fifteen by law. ${ }^{27}$ This frequency becomes all the more significant if it is borne in mind that there is a substantial suspension of constitutional guarantees when the state of siege is declared. However, the Supreme Court has ruled that this state constitutes an "exceptional status, and consequently the interpretation of the powers which are granted by it must be done restrictively, especially when, as in the case of the extent and measure thereof in one of their aspects, discussion and doubt arise." 28 Contrary to the interpretation prevailing in Argentina at this time, we understand, together with two distinguished jurists, Joaquin V. González ${ }^{29}$ and Juan Carlos Rébora, ${ }^{30}$ that the state of siege suspends those guarantees of the civil and political rights only to the extent that they join in repelling foreign attack or suppressing interior disorder, and the suspension must be made effective in each individual case by the exercise of the powers which the state of siege ${ }^{30 \mathrm{a}}$ grants to the President, $i$. e., to arrest or to transfer the persons from one point of the nation to another if they should not prefer to depart from Argentine territory. The opposite interpretation is equivalent to the grant to the executive of the extraordinary powers which Article Twenty-nine of the Constitution condemns.

\section{Relation of the Federal Government to the States or Provinces}

Woodrow Wilson was not mistaken when he stated that the relations between the central and the local powers constitute the crucial problem of the political system of the United States, ${ }^{31}$ and an identical affirmation can be made with respect to the constitutional structure of the Argentine Republic. Here it can be said that the very keystone of the federal state is this balance between the central government and the state governments, neutralizing the constant divergent actions of centripetal and centrifugal forces which struggle constantly to obtain supremacy.

Both in the United States and in Argentina, the states or provinces have delegated to the federal government a definite portion of

27. Quintana, La desnaturalizactón DEt Estado de stTto como INSTRUMENTO DE SUBVERSIÓN INSTITUCIONAI (1946).

28. In re Marcelo T. de Alvear, 167 C. S. N. 317 (1932).

29. González, Manual de la Constitución ARgentina 250-251 (1897).

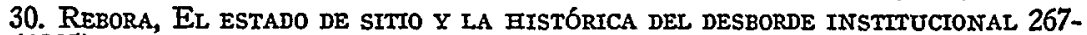
268 (1935).

30a. Article Eighty-three, section nineteen of the new Constitution provides that the Executive, with the knowledge of the Congress, can impose a state of siege in the event of a civil disturbance which dislocates the peace or the activities of the citizens. Such a declaration suspends the constitutional guarantees.

31. Witson, Constitutional Government of the United States 173 (1908). 
power and have reserved the remainder to themselves. In both countries, the states or provinces possess autonomy or self-government. It could be said that the federal and provincial or state governments are independent in their respective spheres. However, the American states have a fuller measure of autonomy than the Argentine provinces; and as an illustrative example may be mentioned the power reserved to the American states to enact their substantive codes-civil, criminal or commercial-a function which in the Argentine Republic has been expressly delegated to the federal Congress. ${ }^{31 a}$

In addition, the constitutional clause which authorizes the Argentine federal government to intervene in the territory of the provinces in a series of situations which it enumerates ${ }^{32}$ has frequently served so that the executive power has established its political supremacy in the provinces, frequently with their acquiescence and even at their request. Almost forty years ago, Matienzo observed: "In a word, federal intervention is accepted willingly in everything which may contribute to the social and economic growth of the provinces. And in the political field, the federal interference is also accepted with great pleasure, whenever it benefits the party to which one belongs; and thus, there is no governor, no legislature, no faction of a provincial legislature, which does not turn its eyes to the President of the Republic or to Congress, whenever they feel weak or in danger. Vice versa, there are no provincial oppositions which do not call him to their support, to depose or subdue the governor of the province." 33

It is interesting to note that between the final constitutional organization of the country and the Revolution of June 4, 1943, the federal government had spent, upon intervening in the provinces, the sum of $\$ 32,071,086.70$. Only on forty-seven occasions was the true constitutional doctrine applied, requiring a law of Congress, while in ninety-five cases resort was had to the simple and convenient executive decree. Such interventions have ranged in duration from two days in the one experienced by Buenos Aires in February 1935 to about three years in San Juan in $1938 .^{34}$

31a. To this the new Constitution adds the power to enact aeronautical, sanitary and social rights codes. Art. 68. And Article Sixty-seven, section sixteen gives the federal government the power to legislate on matters "conducive to the prosperity, hygiene, morals, public health and social welfare."

32. This cannot be compared in scope, however, with Article IV of the United State Constitution.

33. Matifenzo, El gobierno representativo federal en la República ArgenTINA 242 (2d ed. 1917).

34. The first place on the list of provinces which have experienced interventions is occupied by San Juan, with fifteen-four by law and eleven by decree. San Juan is followed by La Rioja, Corrientes, and Catamarca, with fourteen interventions each - La Rioja, five by congressional sanction and nine by executive decree; Corrientes, two by law and twelve by decree; Catamarca, eight by law and six by decree. In 
McChesney Sait has asserted that a federal state and a unitarian state are not more than steps in a series of biological evolution. The unitarian state constitutes the beginning and the end of the process. In an initial step, a unitarian state begins by allying itself with another state for the purposes of common defense. The second phase is the confederation which does not destroy the sovereignty of the member states. In a third step, the federal state is built up in which the sovereignty of the local states is replaced by autonomy, and in which there is a balance between the federal powers and the state or provincial powers. In a subsequent step, upon the breaking up of this balance, the supremacy of the central government over the local governments is produced. The last step of the cycle is the return to the unitarian state, and so on successively. ${ }^{35}$ To the examples of the United States, Germany, and South Africa, which the cited author invokes as examples of his thesis, the Argentine Republic could be added. In fact, both in the United States and in Argentina, the states or provinces at the beginning joined in a confederation ${ }^{36}$ so that later, upon the adoption of the Constitution, they formed a federal state, with a balance more or less adequate between the federal and the local powers. And today, in each country-although with greater intensity in Argentina-one observes the breaking up of that balance and an evident predominance of the federal government over the state or provincial governments. ${ }^{37}$

We do not assert, incidentally, anything new when we indicate (as already has been more authoritatively done by American specialists in political science ${ }^{38}$ ) the strengthening of the central power at the expense of state autonomy carried out in the United States. That centralizing tendency which is observed in almost all the federal states of the world-United States, Mexico, Canada, South Africa, Australia and Brazil, has not failed to be evidenced also in Argentina, with

Jujuy, the federal remedy was applied eleven times, all by decree. The next position is occupied, with ten interventions each, by the provinces of Buenos Aires (five by law and five by decree), Santa Fe (one by law and nine by decree), and Mendoza (three by law and seven by decree). Of the nine occasions when Tucumán had to undergo the federal remedies, four were by virtue of law and five by decree. With seven interventions each are Córdoba (one by law and six by decree) and San Luis (four by law and three by decree). The five interventions which Salta has suffered were by legislative decision once and the remaining three times by decree. Entre Rios has been the province with the fewest interventions, since only on four occasions was there an intervention, three times by law and once by decree. 1 QUINTANA, GobIERNo $\mathrm{y}$ ADAINISTRACIÓN DE IA REPÚBLICA ARGENTINA 46, 47 (1946).

35. Sait, Politicad Institutions 374 (1932).

36. This was accomplished by the Articles of Confederation in the United States, and by the Federal Pact of 1831 in Argentina.

37. See Quintana, Teoría y Práctica ded Estado federai 21 (1943).

38. See, e. g., Ogg \& Ray, Introduction to American Governarent $59-71$ (1945). 
emphasis more or less pronounced than in other countries. Almost ten years ago Professor Dana Montaño stated, "From some time to the present, the natural centripetal tendency of the federal system, which is a universal phenomenon, which consists in the centralization of important governmental and administrative powers, historically or juridically exercised before by the entities which make it up, becomes more aggravated and complicated with the progressive renunciation of the exercise of powers reserved exclusively to the provinces by the constitutional instrument; a renunciation of self-government, which is incompatible with the sentiment and the reality of the provincial personality. Everything is expected from, everything is attributed to, everything is abandoned to the action or to the patronage of the central government. Now it is not only that old practice erected into doctrine, denounced half a century ago by Estrada, as one of the sophisms which destroyed the essence of suffrage and interfered with electoral freedom, a practice which in short originated and developed in the politico-party field. Now it is the subvention, the subsidy, the designations, the national law and national decree, the inspiration in every order and in every and all grounds, the mess of pottage for which the provinces sell their political birthright in the institutional field." 39

The causes of the growing centralization carried out in Argentina are numerous and complex. On the one hand, the inaction of provincial governments, generally due to their poor economic and financial condition, has contributed, as has their lack of initiative and the expectation of everything from the central power. On the other hand, the penetrating action of the federal government has been at work, generally motivated by the necessity of replacing local inertia in such important fields as primary instruction and social assistance, as well as the national centralizing force, which, as we have already indicated, is evidenced in nearly all federal countries, and which is accentuated by the absence of barriers erected by the provincial governments.

The two most powerful instruments of such centralization have been federal intervention in the provinces and economic and financial aid from the central power. We have already dwelt on the frequency with which the powerful remedy of intervention has been applied in Argentina, to the extent that an institution provided by the constituent members as a last resort, and one of an extraordinary nature, has been converted into one of normal and current use. Also, in matters of primary instruction and of taxes, the provinces, by means

39. Montaño, Los Principios fundamentales de la Constitución Nacional, in 47 Revista DE Conferenctas 31 . 
of a system of law agreements, $i$. e., laws sanctioned by the national Congress and to which the provinces subsequently subscribe, have been delegating gradually and increasingly to the central power an important sum of functions which in reality they reserved to themselves under the Constitution. It is thus that the provinces have delegated, by means of these law agreements, to the federal government the collection of internal taxes and the income tax, the receipts from which are distributed among the provinces in accordance with a fixed percentage. Hence, with the weakening of the economic and financial autonomy of the provinces, their political autonomy has declined correspondingly. ${ }^{40}$

The creation of the Secretariat of Labor and Security, with the rank of Ministry and with jurisdiction over the entire country, simultaneously with the transformation of the provincial labor departments into simple delegations of that central body, constitutes another aspect of the strengthening of the central power at the expense of the provinces. This may be said without failing to recognize the necessity of a ministry in that field of administration, but delineating its sphere of action without invading local jurisdiction. In this respect the criterion recently established by the Argentine Supreme Court delineates the federal and provincial powers in labor matters. In 1947, that high tribunal said in Martin $y$ Cia., Ltda. v. J. Erazo, ${ }^{41}$ that federalism ". . . comports in the order of things the assignation to the provinces of specific authority to legislate in labor matters as it does to those other matters related to the public order. . . . This authority is, however, limited by the Constitution, primarily Section Eleven of Article Sixty-seven, relating to civil and commercial legislation . . ."

Emergencies, the Court continued, which endanger social order constitute proper subject matter for provincial legislation, but such emergency situations diminish upon the progressive enactment of national legislation, and a corresponding lessening of the scope of local power results.

"The second limitation is that which results from the supremacy of legislation in the matters in respect of which the legislative powers of the nation and of the provinces are concurrent. Everything which may be regulated by the provincial legislatures in labor matters may be done as long as it is not the subject of regulation on the part of the national Congress, or in case that it has been, in harmony therewith, since said power arises from what is provided in Article One Hun-

40. See Schaffroth, Restauracton financtera 5-10 (1941).

41. 48 Rev. LA Ley 331, 335-336 (1947). 
dred-seven of the Constitution it is obvious that it is not an exclusive power but one enjoyed jointly with the national government to which it is assigned, even in the same language, in Section Sixteen of Article Sixty-seven. But it is in the natural order that such concurrence, in the case of legislations which cannot reach their respective finalities except disposing of the whole in the regulation of a part imposes the recognition of the supremacy of the legislation of the whole . . .

"The third limitation is that which establishes the freedom of interprovincial commerce sanctioned by sub-paragraph nine and twelve of Article Sixty-seven of the Constitution which reserves expressly the regulation thereof to the National Congress." 42

\section{The Federal Government}

The principle of the separation of powers of the government appears as the backbone of both constitutions. However, the draftsmen of the two instruments show a different criterion in the distribution of functions between the three departments or branches of the federal government. There is no doubt that the Convention at Philadelphia placed Congress in the upper vortex of the federal triangle, to the point that it has been said with accuracy that the "Congress of the United States is the central stronghold of the American democracy." 43 Nor is it error to assert that the constituent members at Santa Fe gave to the Argentine Executive notable preeminence over the other two federal powers. It is not superfluous to remember that the Father of the Argentine Constitution, Alberdi, found the solution of all the international evils in organizing an executive endowed with the fullest powers when he said to give to the executive all power possible, but to give it by constitutional means.

The passage of time caused a progressive and slow but sure decline of the American legislative power, fully evidenced recently in the La Follette-Monroney Report. ${ }^{44}$ Along with this weakening of the legislative body, a strengthening of the administrative power was observed.

In the Argentine Republic, since the constitutional organization the political system bore the original sign of the marked executive preeminence in the play of governmental powers, and time accentuated

42. Articie 67, section 11 of the Argentine Constitution authorizes Congress "to issue civil, commercial, penal and mining codes, without the said codes altering local jurisdictions, that application corresponding to the federal provincial courts, depending on whether the things or persons fall within their respective jurisdictions."

43. Giraud, LA CRISE dE LA DEMOCRATIE ET LA RENFORCEMENT DU POUVOIR EXECUTIF 9 (1938).

44. Sen. Rep. No. 1011, 79th Cong., 2d Sess. (1946). 
even more this supremacy, diminishing the original rank of Congress. In this respect it is interesting to remember that in Europe, shortly before the beginning of the last World War, it was maintained that the crisis of democratic institutions in which we then lived was due principally to the weakness of the executive power, and as a probable remedy the strengthening of that department of the government was advocated. In sharp contrast with this fact it was noted that, on the contrary in Latin America, the authority of the President is clear and unequivocal, going to the point of designating as "democratic dictatorship" the presidential system in these Latin American countries.

The development of the Argentine executive power is traceable from the Spanish monarchy as evidenced in the viceroy of the colonial period, through the supreme director established in 1814, the governors of the provinces, and the pathological and anti-democratic development of the system under the tyrant Rosas. The theory of the unipersonal "strong" executive was set forth and systematized by Alberdi who believed that here was one place where the SpanishArgentine Constitution must depart from the model of the United States. ${ }^{45}$

We believe that the Argentine constituent members magnified the role which belongs to the President in the constitutional plan which they elaborated, and that the practice unbalanced even more the relation of the former with the other powers of the government, particularly with Congress. ${ }^{45 a}$ It has been said that the Argentine people of today differs so completely from the people of the preconstitutional era-economically, socially, politically, and raciallythat it is an absurdity to maintain the Executive in the preponderant position then given him because of the difficult circumstances and almost insuperable obstacles which were faced in effecting national organization. The political doctrine has been designated as "anachronistic and anti-republican, repugnant to the progressive development of a modern nation." 46

It must be admitted on the other hand that the strengthening of the executive in general has been facilitated and stimulated by the weak action of Congress in the defense of its sphere of action and of its constitutional prerogratives, due, among other causes, to the fact that almost always the President has been a member of the political party which had a majority in the legislative branch, and many times party solidarity was more potent than the defense of the par-

45. AlBERDr, op. cit. supra note 5, c. xxv.

45a. The new Constitution further strengthens the power of the Executive. See

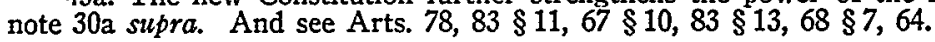

46. Calderón, Derecho constitucionai 286 (1931). 
liamentary body. Precisely, the Buenos Aires newspaper, "La Nacion," stated on August 11, 1940: "The facts reveal that Congress is planning its own ruin in consenting to the usurpation of its privileges by the Executive Power. Not only does it fail to stop the advance, but it does not adopt measures designed to avoid it in the future. In its indifference toward the alteration of the constitutional balance, the chambers are permitting themselves to be despoiled even of the traditional prerogatives of parliaments. . . ."

Also, for some considerable time, there has been manifested a growing tendency to govern by means of decrees, which in many cases have replaced legislative action.

Consequently, the opinion expressed by Professor MacDonald, is not exaggerated, that "In the scheme of Argentine political life [the President] is more important than Congress or the courts, or the two combined. His authority is greater than that of the president of the United States, or of the chiefs of state of most democratic nations." 47

The Supreme Court-considered properly as that characteristic of the American constitutional system which distinguishes it from the other modern political systems ${ }^{48}$ - was adopted by the Argentine Convention, erecting it as the guardian and final and definitive interpreter of the Constitution. The importance which the Court has had in Argentine constitutional history has been extraordinary. It has been asserted that ". . . many pages of [the Constitution] find their true sense and their highest meaning through the decisions of the Court, and of the teachings which they imply," 49 and that "the true Constitution of the Republic is that which springs from the interpretation which has been given to it in one thousand decisions of the Supreme Court of Justice." so

It has been objected that "ordinarily the Court seems rather like a superior tribunal, with functions similar to those of other justice tribunals, and only in exceptional occasions does it assume the exercise of its great power to establish the constitutional interpretation which is expected of it. Its varied jurisprudence concerning the socalled extraordinary remedy, established by Article 14 of Law No. 48, demonstrates, aside from the incongruity which characterizes the former, the tendency of the Court to evade the examination of any

47. MacDonald, Government of the Argentine Republic 190 (1942).

48. See Haynes, The Role of the Supreme Court in Amertcan Government aNd Polrtics 3 (1944).

49. Galto, Prólogo a Felipe S. Perez, Tratado sobre la jurisprudencta de LA CORTE Suprema 14.

50. Id. at 24 . 
constitutional question which may compromise it before public opinion." 51 It has also been said that attacks on the institutional order by means formerly unknown-brought about by social transformations, new methods of commerce, and the complications inherent in the changes of international exchange-do not succeed with the frequency that is necessary to effect its ascendancy; that it makes its strength consist in its immutability. ${ }^{52}$ The Court has also been criticized because its judgments sometimes indicate that all solutions must be extracted from the express or implied intent of the legislature as opposed to the principles of constitutional interpretation employed in the United States. ${ }^{53}$

Despite the criticism and objections that the work of the highest Argentine tribunal may deserve, we cannot fail to recognize that its constant homogeneity and unity has prevented the lowering of the high esteem in which it is held. Its jurisprudence must be seen, by reason thereof, as a firm and sure development; the expression of wisdom and maturity and not of improvisation. And this observation applies to the Court subsequent to its renovation, effected by the political persecution of several of its members, since, in spite of the almost complete modification of its membership, one cannot point out a fundamental departure from the principles established by the jurisprudence of the previous Court. Realizing that the Supreme Court is not in an atmosphere propitious for innovations, one may recall Bielsa, who considers as of the essence of that institution its conservative function in the juridical order in the institutional-jurisdictional sphere. ${ }^{54}$

\section{Revolution and the De Facto Doctrine}

Not always do governments succeed each other regularly in the course of time in accordance with the procedure regulated by the Constitution, but rather on certain occasions revolution puts in power a de facto government. In the United States, from the adoption of the Constitution until the present time, governments have succeeded each other regularly without there having occurred any government of such a nature. On the other hand, in the Argentine Republic, on various occasions, revolutions have given rise to such de facto governments.

51. 3 CALDERon, op. cit. supra note 46 , at 447.

52. Zavalía, Historia de la Corte Suprema de Justicla 11 (1920).

53. Justo, La interpretacion de la ley a propósito de un tratado sobre jurisprudencia de la Corte Suprema, Boletín DE LA BIBLtoteCa DEL Congreso Nactonal 1023 (1941).

54. Bielsa, La pROTECCIÓN CONSTItUCiONAL Y EL RECURSO EXTRAORdINARIO 113 (1936). 
As a result, the Supreme Court has established during the course of the years a series of principles, the systematization of which constitutes an entire de facto doctrine.

\section{Revolution of 1861}

The first jurisprudential case arose upon the fall of the government of the Confederation at the Battle of Pavón, on September 18, 1861. Mitre, who successfully headed the movement against the authorities, was entrusted by the provinces with the foreign relations of the Republic, and to perform them within the constitutional limits of the national executive until Congress might convene and enact legislation as was provided by law for that purpose. Upon the cancellation by General Mitre of payments made to the customs of Rosario, the private citizens affected initiated a judicial proceeding which reached the Supreme Court. The Court held in Baldomero Martinez $y$ Manuel Otero, ${ }^{55}$ that as Governor of Buenos Aires and General in Charge of its armies, Mitre was competent to decide such matters since it was he who provisionally exercised all national powers by virtue of the victory of Pavon and by the assent of the people.

\section{Revolution of 1930}

The Revolution of September 6, 1930, having been successful, the Supreme Court met in extraordinary session, to take into consideration a communication addressed by the President of the provisional Executive Power, Lieutenant General José F. Uriburu, informing the tribunal of the establishment of a de facto government. The Court then subscribed to a decision in which it said:

The provisional government which has just been established in the country, is, then, a de facto government the title of which cannot be judicially disputed with success by persons in so far as it carries out the administrative and political function derived from the possession of force as an instrument of order and social security. Notwithstanding that, if, once the situation becomes normal, in the development of the action of the de facto government, the officers who make it up should ignore the individual guarantees or those of property or others secured by the Constitution, the Administration of Justice charged with making the form that be complied with, would restore them in the same conditions and to the same extent that it would have done with the legal executive power. And this last conclusion, imposed by the very organization of the judicial power, is con-

55. 2 C. S. N. 290 (1865). 
firmed by the declarations of the provisional government, which, in assuming charge has hastened to give oath to comply with and to cause to be complied with the Constitution and the fundamental laws of the nation, a decision which implies the consequence that it is ready to . . . render the aid of the force which it possesses to obtain compliance with judicial judgments. ${ }^{56}$

In the controversy produced by the pardon granted the ex-President Hipólito Irigoyen, the Court said that it mattered not that the pardon sub lite may have been decreed by the de facto Executive Power since the provisional government had been able to use the constitutional powers of the legal Executive Power, having submitted in the exercise thereof to the constitutional provisions and the decisions of justice. ${ }^{67}$

This principle was reiterated in the case of Administracion de Impuestos Internos v. M. Malmonge Nebreda, ${ }^{58}$ where it was said that the provisional President held the same powers as those granted the legal President by Article Eighty-six of the Constitution. Further, it was set forth that the de facto government possessed executive but not legislative or judicial powers, for to allow such a situation would leave to the will of a single person the most delicate and gravest interests of the state, including those guarantees of individual liberties. However, it was recognized that a case might arise where the provisional government, in the absence of a Congress, faced with an extraordinary situation might exercise legislative powers by means of Decree Laws ; such to be given legal sanction only within the abnormality of the situation.

\section{Revolution of 1943}

Upon the outbreak of the revolutionary movement of June 4, 1943, the provisional Executive Power, General Ramirez, made known, to the Court the formation of a provisional government. Citing its decision of 1930, the Court again issued a decree recognizing the de facto administration. ${ }^{59}$

On April 2, 1945, the Court, confirming its previous jurisprudence, established certain basic principles. Having convened to consider a note from the de facto Executive Power which communicated

56. 158 C. S. N. 290 (1930).

57. 165 C. S. N. 213 (1932).

58. 172 C. S. N. 365 (1935); accord, C. Zavalia v. Caja de Jubilaciones de Empleados Civiles, 184 C. S. N. 589 (1939); M. Escalada v. Caja Nacional de Jubilaciones, 179 C. S. N. 409 (1937) ; S. Toranzo v. Gobierno Nacional, 178 C. S. N. 377 (1937); A. Avellaneda Huergo v. Gobierno Nacional, 172 C. S. N. 365 (1935).

59. 196 C. S. N. 5 (1943). 
the Executive's decree appointing Dr. Fernando Dupuy to the Chamber of Appeals of the North, the high tribunal decided not to administer the oath to the magistrate. In his opinion, Judge Repetto said:

Article Ninety-four of the National Constitution and subparagraph seventeen of Article Sixty-seven provide in a categorical manner that the judicial power shall be exercised by one Supreme Court of Justice and by the other inferior tribunals which the Congress should establish in the territory of the Nation. But paragraphs twenty-seven and fourteen, in turn, attribute to Congress, as the local legislature for the capital and the national territories, exclusive jurisdiction for the creation of tribunals of this type.

The Executive Power, de facto, bound himself by oath to comply with the Constitution, and consequently, he could not issue decree No. 4,256, creating a Chamber of Justice in the national territories, inasmuch as, on the one part, the subject matter of the decree is not included in any of the purposes declared by the resolution of June 4, and, on the other, it would lack the double character of urgency and necessity indispensable so that the Executive Power de facto, may exercise, under the guise of an exception, power which the Constitution assigns expressly to the Congress of the Nation. ${ }^{60}$

On the same date, the Court, by reason of a decree of the de facto Executive Power which transferred the federal judge of Santa Fe to San Rafael-that is to say from one province to another-declared that the transfer violated the constitutional guarantee of non-removability of judges. ${ }^{61}$

But it was in the case of Municipalidad de la Capital v. Carlos M. Mayer, ${ }^{62}$ decided on the same day as the preceding ones, that the Supreme Court stated more extensively the basis of its de facto doctrine. In this suit the unconstitutionality of the Decree Law issued by the de facto Executive Power on July 6, 1944, which modified Law No. 189 concerning expropriation by reason of public use (eminent domain) was sought, and in the decision rendered the next day, the Court said :

It was thus that a de facto government was formed under the form of the Executive Power of the Constitution, which, even though it could have by reason of the force which supported it, abrogated the Constitution and issued its own statute, limited itself to unseat the Executive Power and to dissolve the Legislative Power, swearing to comply with the Constitution, and maintain the functioning of the Judicial Power constitution-

60. 38 Rev. LA Ley 51 (1945).

61. 38 REV. LA LEY 53 (1945).

62. 38 Rev. LA Ley 87, 90 (1945). 
ally organized. By reason thereof, the Court, in the performance of an inescapable duty and before the necessity that the country should continue its course under the protection of constitutional rights and guarantees, continued to act in the fullness of its functions, without declining any of its powers, or assuming others than those which corresponded to it constitutionally.

The survival of the Constitution and the continuation of its Judicial Power of constitutional origin are facts pregnant with consequences which cannot be lost sight of and of fundamental and decisive importance to decide the questions of the nature raised in this suit. It is indisputable that the de facto Government has all the powers which the National Constitution grants to the constitutional Executive Power, and the Court has so ruled in previous cases (Judgments: Vol. 165, p. 199; Vol. 169, p. 309; Vol. 178, p. 377). It is indisputable, also that he cannot exercise judicial functions, usurp the cognizance of pending cases, or reestablish those which have lapsed. The contrary would be to grant to the de facto government extraordinary powers and those who would consent thereto would incur the condemnation of Article Twenty-nine of the Constitution.

The Court added that the question relating to the exercise of legislative powers by the de facto Executive Power would be more complex:

The Iegislative Power which it (the Constitution) creates is the genuine representative of the people and its character as a collegiate body is the fundamental guarantee for the real interpretation of the general will. The de facto government is unipersonal, lacks popular representation, and if it maintains the Constitution in force, the restoration of which it proposes according to well known declarations, is a temporary government, between two constitutional governments. However, the necessity of the imposition of the facts makes inescapable to it the exercise of legislative powers which may be indispensable to it to maintain the freedom of the state and to perform the purposes of the revolution; the contrary would lead to chaos and anarchy. But these powers must be limited, carrying to an indispensable minimum the abrogation of the representative principle. The necessity of guarding judicial security, and of preserving the system of the fundamental rights of civil life require it, just as they have been organized by the national representation. To recognize in one man or in a group of men ample legisiative powers is incompatible with the enforcement of the Constitution. Also in point of time, the legislative powers of the government have a limit. Once the country has returned to normalcy, the provisions of such a character cease to have effect in the future, except if ratified by Congress, its previous existence having been effective with relation to accomplished facts. This is, on the other hand, the doctrine which arises from the judgments of the Court. 


\section{Systemization of the De Facto Doctrine of the Argentine Supreme Court}

The de facto doctrine which has resulted from the systemization of the jurisprudence of the Argentine Supreme Court, may be synthesized into the following principles: ${ }^{63}$

(A) The de facto government does not suspend the effective force of the Constitution, since it is a statute to regulate and guarantee the rights of the men who live in the Republic, in time of peace as in time of war, and its provisions could not be suspended in any of the great emergencies of a financial character or of another nature in which the governments might find themselves; ${ }^{64}$

(B) The de facto government possesses the powers which the Constitution confers on the executive power, inasmuch as it is a "government de facto under the form of the Executive Power of the Constitution, which, even though it could have by reason of the power which supported it, abrogated the Constitution and issued its own statute, limited itself to unseat the Executive Power and to dissolve the Legislative Power, swearing to comply with the Constitution and maintain the functioning of the Judicial Power constitutionally organized"; ${ }^{65}$

(C) The de facto government has the same powers as the de jure government, never greater, inasmuch as "if the force of necessity requires that the same powers may be acknowledged in the de facto official as in the legal one, nothing justifies that greater ones be attributed to him"; ${ }^{\text {es }}$

(D) The de facto government "cannot exercise judicial functions, assume the cognizance of pending cases or restore those which lapsed"; ${ }^{67}$

(E) The de facto government is subject to the control of the Judicial Power; ${ }^{68}$

63. In setting forth the jurisprudence of the Argentine Supreme Court, the term de facto government is used in the sense in which the Supreme Court uses it. It should be noted, however, that we consider this term inadequate, since in reality we should speak of the de facto executive pozver.

64. Compañía Azucarera Tucumana v. Prov. de Tucumán, 26 Rev. Jur. ArgenTINA 903 (1927). (1945).

65. Municipalidad de la Capital v. Carlos M. Mayer, 38 Rev. LA Ley 87, 90

66. Administración de Impuestos Internos v. M. Malmonge Nebreda, 165 C. S. N. 365 (1933). (1945).

67. Municipalidad de la Capital v. Carlos M. Mayer, 38 Rev. LA Ley 87, 90

68. Ibid. 
(F) In principle, the de facto government lacks legislative powers, but exceptionally the necessity of the occasion may justify their exercise when indispensable to the maintenance of the state, ${ }^{69}$ as would be those provisions of a fiscal nature made necessary by the progress of the nation and those which would answer other necessities of an urgent nature $\mathrm{e}^{70}$-a rule which requires that the measure possess the double character of urgency and necessity; ${ }^{71}$ also, whenever they are indispensable to carrying out the purposes of the revolution, ${ }^{72}$ such as laws of an electoral character or those meant to improve the social conditions of the working classes, ${ }^{73}$ this having been established as the express purpose of the revolution.

(G) The exercise of these legislative powers is further limited inasmuch as: (1) the abrogation of the representative principle must be held to an absolute minimum; ${ }^{74}(2)$ individual rights and guarantees must not be adversely affected; (3) once there is a return to normalcy such provisions cease to have effect unless ratified by Congress; ${ }^{75}$ and (4) the power is not extended to the establishing of crimes and penalties or to increasing existing penalties, or modifying the penal code then in force. ${ }^{76}$

(H) The de facto government is unipersonal, lacks popular representation and if it retains in force the Constitution, it is a temporary government, between two constitutional governments. ${ }^{77}$

A fundamental change in the make-up of the Supreme Court, caused by the retirement of its President and the removal through political action of three other members is reflected in the one important modification of the principles previously set forth in the de facto doctrine. Thus, in the case of Enrique Arlandini ${ }^{78}$ the Court said, ". . . that to the extent in which it is necessary to legislate in order to govern, a de facto government has legislative powers, without the determination of that necessity . . . being subject to judicial revision. What continues to be subject to said revision by means

69. Ibid.

70. Id. at 93 (concurring opinion).

71. 38 Rev. LA LEy 51, 52 (1945). (1945).

72. Municipalidad de la Capital v. Carlos M. Mayer, 38 Rev. LA LEY 87, 90

73. $I d$. at 93 (concurring opinion).

74. Id. at 90 .

75. Id. at 90 .

76. Carlos Anders y otros, 42 Rev. LA LEy 21 (1946). (1945).

77. Municipalidad de la Capital v. Carlos M. Mayer, 38 Rev. La Ley 87, 90

78. 47 Rev. LA Ley 802, 803 (1947). 
of the remedy of unconstitutionality is the basis or contents of the legislative sanctions of the de facto governments as well as those which arise from those legally established."

On October 1, 1947, in the case of Ziella v. Smiriglio Hnos, ${ }^{79}$ the same tribunal decreed, ". . . that the decree-laws issued by the de facto government are valued by reason of their origin and since they have the force of law they continue in force even though they have not been ratified by Congress as long as they are not repealed in the only manner in which they may be so, that is to say, by other laws." These new principles modifying those previously set forth, have already been ratified in numerous subsequent cases.

79. 48 REv. LA LEY 361 (1947). 